This document is the accepted manuscript version of the following article:

Oliveira, E., \& Hersperger, A. M. (2018). Disentangling the governance

configurations of strategic spatial plan-making in European urban regions, planning practice \& research. Planning Practice and Research.

\title{
Disentangling the Governance Configurations of Strategic Spatial Plan-making in European Urban Regions
}

\begin{abstract}
Strategic spatial plans are planning tools aimed at steering the medium- to long-term spatial development goals of urban regions. Whilst there is some consensus regarding the objectives of strategic spatial plans, it is less clear as to how strategic spatial plans are conceived. Specifically, the literature has scarcely investigated how governance configurations impact strategic spatial planmaking processes. Hence, through in-depth interviews with regional planning experts, as well as document analysis and a literature review, this paper is aimed at assessing and disentangling how territorial governance configurations influence contemporary practices in strategic plan-making in 14 European urban regions. The findings allow us to distinguish three dominant practices of strategic plan-making across Europe: i) plan-making shaped by consensus building and multilevel government cooperation; ii) plan-making shaped by the involvement of profit-oriented actors and negotiations, and iii) plan-making shaped by consolidated planning practice. In addition, the findings also show that plan-making processes have increasingly being co-opted by dominant neo-liberal agendas. We, therefore, argue that, to truly grasp plan-making practice, it is necessary to scrutinize who rules and who is ruled while negotiations are unfolding, as well as the extent to which private actors' interests influence how spatial development goals and strategies are defined. The paper contributes to the expansion of current knowledge by providing empirically based evidence of how strategic spatial plans are framed and shaped by place-based governance configurations.
\end{abstract}

\section{Keywords}

Plan-making, Strategic spatial planning, Territorial governance, Urban regions, Spatial development.

\section{Introduction}

Strategic spatial planning is increasingly practised throughout the world to develop a synchronized vision for guiding the medium- to long-term development of urban regions (Albrechts, Balducci \& Hillier, 2017). Strategic spatial planning is also employed as a response to economic and social challenges and in supporting structural changes, for example, from an industry-based to a serviceoriented urban region (Oliveira, 2016a; Ogilvy, 2002). Strategic spatial planning includes both planmaking and plan implementation phases (Albrechts, 2010). This paper is focused on the strategic spatial plan-making phase.

The literature defines strategic spatial plan-making as a social and collective process, which brings multiple actors from the private and public sectors together to frame spatial dynamics, elaborate short-term actions, and define long-term development visions and strategies (Healey, Khakee, Motte \& Needham, 1997[2006]; Albrechts, 2004; Amin \& Thrift, 1995). Moreover, strategic plan-making enables different forms of popular and expert knowledge to be generated, exchanged, managed and used in a manner that leads to more transparent and legitimate spatial interventions (Legacy, 2012). In a number of critical case accounts, Healey (2009) stresses the relational nature of strategic planmaking processes. This relational nature implies interconnections between multi-actor knowledge sources, the involvement of public and private interests within a territorial-based or place-based governance landscape (see also van Assche, Duineveld \& Beunen, 2014). Strategic spatial planmaking is, therefore, as much about forming strategies and mobilizing actors and resources as it is 
about designing cooperative networks across multiple levels of government (Healey et al., 1997[2006]; Amin \& Thrift, 1995) and negotiations by which planning intentions, i.e., new housing developments, allocation of retail facilities, improvements in the transportation network, maintenance of a public space or expansion of a green area etc., and demands of interest groups are exchanged in an effort to ensure jointly produced outcomes (Ruming, 2012). Strategic spatial plans have the capacity to improve human settlements and overall quality of life, if the plan-making process is understood as a form of storytelling, which contemplates more dynamic modes of decision-making, including coordination, legal frameworks and place-based governance (Lai, 2018; Healey, 2009; Albrechts, 2004).

While there is some consensus that strategic spatial planning encourages broad cooperation among private actors and governments, along with the establishment of networks reaching supranational entities such as the European Union (EU), there are some considerable differences across Europe in the way strategic spatial plans are prepared. Healey et al. (1997[2006]) contributed to this debate two decades ago when editing the book Making Strategic Spatial Plans - Innovation in Europe. Although this work was focused on understanding strategic spatial plan-making, by using an institutionalist approach, it is regarded by this current paper as a starting point for the analysis of current strategic spatial plan-making practices in European urban regions.

Since the release of the above-mentioned edited volume from 1997, a number of scholars has argued that not only institutional settings but also various governance configurations influence spatial planning processes in general (Hersperger et al., 2018; Davoudi et al., 2008; Laurian et al., 2004; Nuissl \& Heinrichs, 2011) and strategic spatial plan-making efforts in particular (Schmitt \& van Well, 2016a; Nadin et al., 2016; Stead, 2013, 2014). However, most of the existing studies fail to disentangle (or to specifically detail) how these governance configurations play a role in planning practice. For example, Gualini (2008) considers that scholarship on neither spatial planning nor governance has been able to unveil the role that governance configurations play in the processes of strategic spatial plan-making. Reimer, Getimis and Blotevogel (2014) stress that few efforts have been made so far to systematically reveal what governance has to offer to the debates regarding strategic spatial planning. Oliveira and Hersperger (2018) emphasize that, given the diversity of spatial planning systems in Europe, the EU discourse on territorial development, along with an evergrowing dominance of market-led values in spatial planning, there is increasing demand for specific knowledge on how strategic spatial plans are effectively prepared in practice (see also Oliveira, 2016b). In addition, Walsh (2014) contends that the spatial planning literature could take full advantage of a critical engagement with the role of territorialism and territorial governance in defining socio-spatial settings, which trigger processes of strategic spatial plan-making.

Nuissl and Heinrichs (2011) and van Well et al. (2016) argue that a robust exploration of the theoretical and empirical linkages between governance and spatial planning practice is yet to be made. Moreover, the findings generated by a European Spatial Planning Observatory Network (ESPON) project reinforces the need for additional research into a systematic comparative analysis of more place-based governance configurations and spatial planning practices across Europe (see Nadin et al., 2016, for the goals of the ESPON 'Comparative Analysis of Territorial Governance and Spatial Planning Systems in Europe' [COMPASS] project). Through a multiple-case study exploration, the present paper provides a contribution to fill this gap. 
To contribute to fill this gap, the paper is aimed at assessing and comparing how governance configurations influence contemporary practices in strategic plan-making within European urban regions. The urban regions of Barcelona (Spain), Cardiff (Wales, UK), Copenhagen (Denmark), Dublin (Ireland), Edinburgh (Scotland, UK), Hamburg (Germany), Hannover (Germany), Helsinki-Uusimaa (Finland), Lyon (France), Milan (Italy), Oslo-Akershus (Norway), Stockholm (Sweden), Stuttgart (Germany) and Vienna (Austria) were selected as case studies. We knew from the outset of our investigation that the 14 selected urban regions were embedded in dissimilar institutional settings (in line with the findings of Oliveira \& Hersperger, 2017), as well as in various spatial planning systems (in line with the findings of Nadin et al., 2016). However, we did not know the extent to which governance configurations affected their strategic spatial plan-making practices.

The assessment of strategic spatial plan-making in these urban regions was developed by drawing on the qualitative analysis of semi-structured interviews with regional planners, who offered a broad yet experientially informed view of strategic spatial plan-making processes in the selected cases. Three interviews per case study were conducted. Even though we tried to interview a larger number of experts, this aim was not met and thus we acknowledge this as a limitation of this study. To overcome this limitation, we also performed an analysis of supportive documents, such as land use policy documents, and the academic and policy-oriented literature specifically on the case studies. This data triangulation procedure was important in order to support the generalization of the findings. These methodological steps are in line with recent studies on policymaking conducted by Dawson et al. (2017) and on territorial governance in project development by Schmitt and van Well (2016b).

Following this introduction, the paper continues by reflecting on previous studies to provide the theoretical background to this study. Then, the research methods are detailed. The fourth section discusses the findings. The concluding remarks of the paper accentuate the common practices in strategic spatial plan-making across Europe, i.e., plans are the result of negotiations, an ever-growing involvement of private interest groups and multilevel government cooperation along with the dominance of neo-liberal agendas. These overall remarks help to push research into the crossfertilization of governance configurations and current practices in strategic spatial planning forward. The paper ends by reflecting on the conceptual and methodological limitations of the study.

\section{Theoretical background of the study}

One of the various challenges in studying strategic spatial plan-making is to find common ground among different approaches to spatial planning and creating strategic plans. The work of Healey et al. (1997[2006]) on strategic spatial plan-making in the European context provides the basis for the case study analysis presented in this paper. Two main reasons substantiate this choice. First, the aforementioned study by Healey et al. focused on processes of strategic spatial plan-making at the urban regional scale. Second, it was elaborated based on qualitative research and thus the planmaking processes were embedded in different social, economic and cultural realities, which are useful for comparing current practices. Healey et al. (1997[2006]) also emphasized that the way in which strategic plans were made differed considerably between 1986 and 1995, albeit typically dominated by multilevel governance arrangements involving national and regional governments and private actors. Despite the variation in strategic plan-making processes across the cases, Healey et al. 
(1997[2006]) reported some commonalities. For example, their analysis showed that economic considerations dominated the spatial plan-making agenda, although spatial planners were also struggling to balance environmental and economic interests. The dire need to strengthen the competitive position in the global market was among the main economic interests impacting the strategic spatial plan-making process within this timeframe (1986-1995). Overall, Healey et al. (1997[2006]) accentuated the interplay between various political, economic, social and environmental pressures and strategic spatial plan-making in their selected cases. A noteworthy outcome of a strategic plan-making process may not simply be a new strategic plan; rather, it can also be a broad, co-produced and shared discourse about long-term spatial transformations (Albrechts, 2010; Healey, 1996; Faludi \& van der Valk, 1994) as well as a new institutional capacity to better deal with strategic spatial planning (cf. Oliveira and Hersperger, 2018; Lai, 2018; Olesen, 2014, Flyvbjerg, 2004).

Even though the notion of governance entered territorial development debates and policymaking agendas worldwide many years ago (Sellers et al., 2017; Hooghe \& Marks, 2010), it only started to be understood as a driving force of spatial planning processes shortly after 2000 (ESPON \& Nordregio, 2013; Stead, 2013; Faludi, 2012). For instance, Stead (2014), along with Davoudi et al. (2008), argued that, as territorial governance was specifically focused on managing overall place-based development from a strategic and integrative perspective, strategic spatial planning processes started to be analysed in light of governance (Nadin et al., 2016; Schmitt \& van Well, 2016a; Nuissl \& Heinrichs, 2011). Schmitt and van Well (2016a), based on ESPON and Nordregio (2013), identified territorial governance arrangements and policy integration as key processes of spatial project development across Europe. While Legacy (2012) argues that the definition of territorial development paths in Australia was defined not in an institutional void but within a deep conundrum of governance configurations, Buijs et al. (2017) and Kahila-Tani et al. (2017) highlight that citizen participation and governance settings played a primary role in the preparation of urban master plans in Finland. Despite the value of these studies in underlining the influence of governance configurations in spatial planning, they do not clarify how this influence unfolds in the context of contemporary practices in strategic spatial plan-making. Specifically, many questions remain in terms of potential practices and alternatives. This paper intends to contribute to addressing this gap, thus paving the way for additional research. The research method employed is discussed below.

\section{Research method}

A qualitative method of research by means of in-depth interviews, document analysis and a literature review was employed in this multiple-case study paper. Case studies are an appropriate research strategy for seeking insight into the dynamics of a specific territorial and institutional setting (Eisenhardt, 1989). The cases studied in this paper were designed according to a multiple-case study method whereby all cases 'serve a specific purpose within the overall scope of inquiry' (Yin, 2003, p. 47). This method is justifiable because the multiple-case study design also facilitates the exploration of differences and similarities in territorial governance configurations within and between cases (Schmitt \& van Well, 2016b). These authors also advocate that territorial governance configurations can only be truly understood by performing research using qualitative methods within a specific territorial context (p. 63). Dawson et al. (2017) and Legacy and Leshinsky (2016) have adopted a similar method of data collection and analysis in their strategic spatial planning evaluation. 


\subsection{Selection of case studies}

The urban regions of Barcelona, Cardiff, Copenhagen, Dublin, Edinburgh, Hamburg, Hannover, Helsinki-Uusimaa, Lyon, Milan, Oslo-Akershus, Stockholm, Stuttgart and Vienna were selected for this investigation. These cases have been chosen for the following reasons: (i) the cases are located in countries with different approaches to strategic spatial planning; (ii) they are embedded in placebased or territorial-specific governance settings, some of which have directly elected regional parliaments (Hannover and Stuttgart), while others are merely the result of multilevel cooperation (Oslo-Akershus) or are in the process of a transition from informal organizations to a directly elected regional assembly (Helsinki-Uusimaa); and iii) these 14 cases represent a sample of a larger group of European urban regions involved in a long-term research project to which the findings of this paper contributes.

While some of the cases are classified as city regions, as in Helsinki-Uusimaa, or as metropolitan areas, as in Barcelona and Milan, others assume the designation of a 'greater area', as in Copenhagen, or are simply regions, as in Stuttgart and Hannover. In this paper, we treat all the case studies as urban regions. In addition, the public entities in charge of the strategic spatial planning process have adopted dissimilar designations for their strategic plans, including 'a strategic regional plan', as in Hannover, 'a strategic development plan', as in Edinburgh, and 'a regional plan for land use and transport', as in Oslo-Akershus. Despite these varied designations, in this paper, we treat all the different plans as strategic spatial plans at the urban regional scale.

\subsection{Data collection}

The primary data to support the present investigation were collected by conducting 42 qualitative, semi-structured interviews with senior regional planners responsible for the processes of strategic planning. Academics and representatives of planning organizations were also interviewed. Interviewing planners and planning experts, as we did, is critical in order to effectively develop a comprehensive overview of strategic plan-making practice. Planners often have multiple roles in the design phase of plans. In an ideal scenario, spatial planners act as moderators, trying to balance expert and tacit knowledge as well as the perspectives of investors, landowners and governments (Paasi \& Zimmerbauer, 2016). It is important to underline that the interviewees were the most knowledgeable persons regarding strategic spatial plan-making processes, as this was among our primary requests ahead of the interviews. The main affiliations of the interviewees in each case study and the assessed strategic regional plans can be found in Appendix A.

The interviews were conducted using an interview guide expanded according to the literature (Schmitt \& van Well, 2016a; Legacy, 2010; Davoudi et al., 2008; Healey et al., 1997[2006]). Overall, the interviewees were asked to: i) characterize in detail the strategic spatial plan-making process; ii) identify and detail as specifically as possible the governance configurations in steering plan-making processes; and iii) identify and provide examples of the main planning intentions and demands (e.g., public spaces, retail facilities, new housing developments, infrastructure) of actors such as those from housing developers, retail representatives or nature conservation groups. Interview data were triangulated with data collected through the analysis of supporting documents (e.g., Nordregio, 2015; ESPON, 2007; Finlex, 2003; CEC, 1997) and a literature review of the case studies. 
Although many data were collected, for this paper, we only analysed data that contributed to the objective of the paper: assessing and comparing territorial governance configurations in strategic spatial plan-making practice in the selected European urban regions. The remaining information was analysed elsewhere (e.g., Oliveira \& Hersperger, 2018; Hersperger et al., 2018).

\subsection{Data analysis}

The interviews were carried out in English at the interviewees' workplaces between May and November 2016. The interviews lasted, on average, 90 minutes and were recorded digitally and subsequently fully transcribed. The interview transcripts were first organized in alphabetical order by case study and a single PDF was created. Second, the transcripts were manually coded for 'planmaking', 'plan', 'regional plan', 'plan process', 'planning practice', 'preparing the plan', 'making', 'process' and 'strategic plan', as well as 'governance configurations', 'governance elements', 'governance configurations', 'governance' and 'territorial governance'. Third, concrete examples were located, including planning intentions and demands during the preparation of strategic plans, e.g., housing, retail, transport connectivity and green, grey and blue areas, or the nature of the actors involved, i.e., profit-oriented economic and environmental NGOs. The findings of the interviews are discussed below, following similar procedures to those used in Healey et al. (1997[2006]) and the relevant literature on strategic spatial planning.

\section{Disentangling the governance configurations of strategic spatial plan-making processes}

Our analysis shows that current strategic spatial plan-making practices are characterized by governance arrangements sustained by consensus building, multilevel government cooperation, negotiations, and private interest groups' involvement and consolidated planning practices. Having disentangled territorial governance configurations in plan-making across the 14 urban regions allows us to distinguish three dominant practices of strategic spatial plan-making. Firstly, there are cases in which plan-making processes are predominately the result of consensus building and multilevel government cooperation, e.g., Region Hannover, Oslo-Akershus, Greater Dublin Area, Greater Copenhagen, Helsinki-Uusimaa and Milan. Secondly, in some urban regions, private interest groups, through negotiations, play a key role in the preparation of strategic regional plans, e.g., Cardiff, Vienna, Edinburgh and South East Scotland, Lyon and Hamburg. Finally, in a few other selected cases, the consolidated planning practice is paramount during the plan-making process, e.g., Barcelona, Stockholm and Stuttgart. In the following paragraphs, we define these distinct governance configurations and compare plan-making practices across the 14 case studies.

Overall, our analysis also reveals a tendency to make strategic regional plans more formal and institutionalized, contradicting Healey et al.'s (1997[2006]) study, which reported a propensity of strategic spatial planning processes to become informal. For example, in the Finnish urban region of Helsinki-Uusimaa, governance reform is currently underway to institutionalize a directly elected regional parliament and thus make the strategic spatial plan, 'Regional Land Use Plan for HelsinkiUusimaa 2016', legally binding for local government authorities. In most of the cases studied, local tiers of government were expected to comply with the strategic spatial plan produced at the urban regional level, in turn requiring cooperation in prioritizing planning intentions and the overarching strategy. The findings also show that private interest groups influence strategic spatial plan-making through negotiations for a new housing settlement or a retail facility on the outskirts of the urban region. 
Furthermore, in most of the strategic spatial plan-making processes assessed, neo-liberal interests have been playing a role in defining strategies and long-term territorial goals; in this regard, planmaking is increasingly open to negotiations involving predominately private groups, which represent economic and financial interests. However, the assessed plan-making processes are still led by public authorities, such as regional governments, e.g., Region Hannover and Verband Region Stuttgart. These findings are in line with those of Albrechts (2006) and Kunzmann (2000), who argued that market-oriented forces would pay a dominant role in strategic spatial planning in the years to come, as well as those of Oliveira and Hersperger (2018) who stressed that the law of the market is unrelenting in current strategic spatial planning practice. In their study on plan-making in Europe, completed 20 years ago, Healey et al. (1997[2006]) also highlighted that economic influences were playing a leading role in shaping spatial plans in urban regions.

\subsection{Plan-making shaped by consensus building and multilevel government cooperation}

Consensus building is a process that incorporates the interests and perspectives of public and private actors, who together coordinate their decision-making in a search for common ground, while avoiding and overcoming conflicts of interest (Foster \& Barnes, 2012). Consensus building is thus the result of multilevel government cooperation (Davoudi et al., 2008). Multilevel government cooperation is a process involving the purposeful and collaborative alignment of the interests and perspectives of public governments at the national, regional and local level (Malone \& Crowston, 1990). Multilevel government cooperation supports consensus building. In Region Hannover, the plan-making phase of the 'Regional Spatial Planning Programme 2016' was a process formally coordinated by the planning department of the regional government. Region Hannover, a regional entity with a directly elected regional parliament, played a fundamental role in seeking cooperation from municipalities in order to reach a consensus regarding planning intentions, for instance, on new housing developments, the allocation of retail facilities and the expansion of the intra-regional public transport network. In contrast, in Oslo-Akershus, the preparation of the 'Regional Plan for Land Use and Transport in Oslo and Akershus 2015' was the outcome of informal multilevel government cooperation, i.e., a working group composed of representatives of the counties of Oslo and Akershus, together with representatives of the 22 municipalities of Akershus County. A certain planning intention was integrated into the strategic plan only after every local authority was consulted and each perspective was clearly understood and prioritized. Achieving consensus through widely accepted benefits of multilevel cooperation was essential for the approval of the regional plan for the Oslo-Akershus urban region.

In comparison with the cases of Hannover and Oslo-Akershus, strategic spatial plan-making in the Greater Dublin Area was also the result of multilevel cooperation, but the entity in charge of establishing cooperative links and build consensus, the Eastern and Midland Regional Assembly, comprises public, private and mixed nature actors. These actors, including the Dublin Chamber of Commerce, brought together resources, tools and respective interests in order to prepare the 'Regional Planning Guidelines for the Greater Dublin Area 2010-2022'. However, within Dublin, municipalities have a weak decision-making capacity when compared to local government in Nordic countries. For instance, plan-making in Greater Copenhagen is the result of a bottom-up and topdown approach to strategic regional planning. Coordinated decision-making between the Danish Business Authority and the municipalities constituting Greater Copenhagen is a primary practice. The 
municipalities played a key role in the preparation of 'The Finger Plan 2015 - A Strategy for the Development of Greater Copenhagen' by proposing the allocation of transportation infrastructure and improvements to the public parks network, as well as demanding more housing and employment-related land. The meetings with municipalities entailed negotiations about which desirables had to be included in the 'Finger Plan' and which were to be excluded. Danish municipalities have a strong political and decision-making authority/capacity in terms of spatial planning, which impacts on how they embrace the strategic spatial plan-making process. In the assessed Finnish case, the early stages of strategic spatial plan-making are characterized by coordination between the Helsinki-Uusimaa Regional Council (HURC) and municipalities in the urban region, as well as between the HURC and the Finnish national government. The regional transportation network and logistics infrastructure are often fundamental matters of debate. Consensus building is a key configuration in the success of plan-making efforts associated with the 'Regional Land Use Plan for Helsinki-Uusimaa 2016'. The establishment of cooperation ties between Città Metropolitana di Milano i.e. Milan urban region and municipalities is central to the whole practice of strategic spatial plan-making at the urban regional level. In order to provide inputs to the strategic plan, municipalities interact with local interest groups in order to take account of their planning intentions and demands.

\subsection{Plan-making shaped by the involvement of profit-oriented actors and negotiations}

Private interest groups are groups representing economic-oriented or for-profit interests. They are an inherent part of the planning process because they pursue their own stakes in the plan-making process (Burby, 2003). Interest groups are directly involved in negotiations. Negotiation is the process of setting up priorities by balancing the interests of the public entity steering the planmaking process and private interest groups (Barnes et al., 2012). Negotiation involves private interest groups and public authorities, such as regional and local governments (Tasan-Kok, 2008). These actors come together to negotiate about various economic, social and environmental planning intentions and demands (Halpin, Fraussen \& Nownes, 2017). Negotiation can directly influence what is included in and excluded from the strategic spatial plan and aids in understanding how strategic spatial plans are shaped by governance configurations (Deyle \& Slotterback, 2009). According to Baarveld, Smit and Dewulf (2015) and Shmueli, Kaufman and Ozawa (2008), negotiation facilitates the allocation of financial, human and natural resources, while helping to overcome implementation conflicts that often emerge among interest groups and between interest groups and governments. While some authors are critical regarding the involvement of private interest groups in the realm of strategic spatial planning (Olesen, 2014), other scholars contend that the involvement of various groups in the strategic plan-making processes can provide planners with a tool that can effectively contribute to both stronger plans and planning intentions that are more likely to be implemented in reality (Burby, 2003). In this respect, Albrechts $(2004,2006)$ asserts that interest groups possess valuable substantive and procedural competences, while that their participation in strategic spatial plan-making processes helps to legitimize the contents of the plan. The involvement of various actors at the urban region level, such as housing developers or those on the environmental side (Natural Resources Wales) were identified as a primary feature in Cardiff's 'Local Development Plan 20062026'. In this UK urban region, plan-making is also characterized by negotiations unfolding between governmental entities and private interest groups, for instance, to decide on the transportation infrastructure, such as park-and-ride facilities, new bus routes or details of a regional light rail system. 
Similarly, negotiations between local governments and private interest groups, mainly from the housing and transportation sectors, were identified in the strategic plan-making process related to the 'Strategic Development Plan 2016 for Edinburgh and South East Scotland'. These negotiations are a 'give-and-take' exercise in which private interest groups, such as housing developers, demand land for a new housing settlement and public entities request their support in infrastructure provision. This kind of exercise often implies the commitment of public entities to facilitating certain developments, such as the allocation of land for housing or commercial use, in exchange for the support of private interest groups with respect to infrastructure provision, from roads to public parks. In contrast, making strategic spatial plans at the urban regional level in Vienna (and elsewhere in Austria) is a highly complex process. The plan-making for the 'Planning Cooperation for the Spatial Development of the City Region of Vienna, Lower Austria and Burgenland 2011' was initially considered to be highly successful and effective, as it was able to bring together multiple interest groups, mainly holding economic interests, in a coordinated manner. Given that municipalities in the Vienna urban region have a strong political and decision-making capacity regarding spatial planning, current attempts to expand the strategic spatial planning approach at the regional level remains challenging.

In the Lyon urban region, the Schéma de cohérence territoriale de l'Agglomération Lyonnaise 2030 reflects the involvement of a number of interest groups mainly from the industrial and housing sectors. Plan-making is also characterized by the commitment from environmental NGOs and agriculture representatives to improving green infrastructure for food production and recreation. During strategic plan-making, several negotiations between private interest groups (real-estate developers, chambers of industry and of retail) and the public authority in charge of organizing the planning process (i.e., Le Sepal) are essential characteristics of strategic spatial plan-making. In contrast, in the German case of Hamburg, the Hamburg Metropolitan Region works on an informal basis, which hinders its ability to be involved in strategic plan-making processes.

\subsection{Plan-making shaped by consolidated planning practice}

Consolidated planning practice refers to the experience of dealing with strategic spatial planning at the urban-region level, which strongly facilitates the entire plan-making process (Shmueli, Kaufman \& Ozawa, 2008). For example, the consolidated planning practice of the Àrea Metropolitana de Barcelona in dealing with strategic plan-making eases the whole strategic plan-making practice. Similarly, the experience in dealing with strategic spatial planning at the urban region level of Stockholm County Council (SCC) facilitated the plan-making process for the 'Regional Development Plan for the Stockholm Region' (RUFS) for 2010 and 2050 because SCC was fully aware of the primary actors involved, the resources available and the overall strategy steering future spatial developments in the Stockholm urban region. The RUFS plan-making process started with the framing of a number of socio-spatial, spatial-economic, cultural and environmental issues, as well as the definition of goals and visions for the region. The success of this diagnosis phase was due to the consolidated planning practice of Stockholm regional- and local-level authorities. Furthermore, in the German urban region of Stuttgart, the strong political and decision-making capacity of Verband Region Stuttgart (VRS) results in the effectiveness of strategic spatial plan-making and enriches multilevel engagement within VRS, the municipalities and place-based actors on matters such as the location of new housing developments and new industrial sites or improvements to the public transport network. 


\section{Conclusion}

This paper has assessed and compared how consensus building, multilevel government cooperation, private interest groups' involvement, negotiations and consolidated planning practice, here defined as territorial/place-based governance configurations, influence contemporary practices in strategic plan-making in 14 European urban regions. The three empirically derived types of governance configurations shaping plan-making are expected to help sharpen future analysis. These three types of practices reflect the dominant governance configurations influencing processes of strategic spatial planning in the assessed cases, i.e., while some of the governance configurations occur in various cases; the three typologies emphasize the prevailing ones. The argument put forward here is that understanding current strategic spatial plan-making practices, by paying particular attention to governance configurations, will serve analysts of spatial planning, planning practitioners, and students and researchers in general, helping them to better understand how short- and long-term strategies for future urban regional development are defined and integrated in strategic plans at the urban regional level.

Despite our belief that this typology of 'dominant practices of plan-making' will push out research boundaries, we acknowledge that, to truly grasp the extent to which governance configurations influence processes of strategic spatial plan-making, it would also be relevant to directly investigate lobbying activities and power relations within the plan-making process. It would also be insightful to investigate the role of local planners and local leaders, as well as the extent to which the existence (or absence) of financial mechanisms influences an overall strategy at the urban regional scale. Another limitation of this study relates to the methodology employed, mainly regarding the number of interviewees and their professional backgrounds. It would have been interesting to additionally interview private interest groups, such as housing developers and regional transportation authorities.

We are, however, confident that these limitations pave the way for future research, rather than threaten the theoretical and empirical meaningfulness of the paper. The findings of this paper, together with additional input from further studies to be developed concerning the investigation of strategic spatial plan-making in other urban regions, can help make informed decisions and improve the understanding of how strategic spatial plans guide development and contribute to spatial transformation.

\section{References}

Albrechts L., Balducci A. \& Hillier J (Eds.) (2017) Situated Practices of Strategic Planning - An International Perspective. (Oxon, UK and New York, USA: Routledge).

Albrechts, L. (2004) Strategic (spatial) planning reexamined, Environment and Planning B, 31, pp. 743-758.

Albrechts, L. (2006) Shifts in strategic spatial planning? Some evidence from Europe and Australia, Environment and Planning A, 38(6), pp. 1149-1170.

Albrechts, L. (2010) How to Enhance Creativity, Diversity and Sustainability in Spatial Planning Strategic Planning Revisited. in: M. Cerreta, G. Concilio and V. Monno (Eds) Making Strategies in Spatial Planning: Knowledge and Values. Dordrecht, the Netherlands: Springer Science + Business Media B.V, pp. 3-25. 
Amin, A. \& N. Thrift (1995) Globalisation, institutional "thickness" and the local economy. In Managing cities, P. Healey, S. Cameron, S. Davoudi, S. Graham, A. Madanipour (Eds.), 91-108. Chichester: John Wiley.

Baarveld, M., Smit, M., Dewulf, G. 2015. Negotiation processes in urban redevelopment projects: Dealing with conflicts by balancing integrative and distributive approaches. Planning Theory \& Practice, 16 (3), 363-384.

Barnes, W., Foster, K.A. \& Malakoff, L. (2012) Getting Things Done Together: A Workbook for Achieving Goals Regionally, National League of Cities, Center for Research and Innovation, Washington, USA. Available here (accessed 08 October 2018).

Buijs, A.E., Mattijssen1, T.J.M., Van der Jagt, A.P.N., Ambrose-Oji, B., Andersson, E., Elands, B., Møller, MS. (2017) Active citizenship for urban green infrastructure: fostering the diversity and dynamics of citizen contributions through mosaic governance. Current Opinion in Environmental Sustainability, 22(October), pp. 1-6.

Burby, R.J. (2003) Making Plans that Matter: Citizen Involvement and Government Action. Journal of the American Planning Association, 69(1), pp. 33-49.

$\mathrm{CEC}=$ Commission of the European Communities (1997) The European Union Compendium of Spatial Planning Systems and Policies. Regional Development Studies. Luxembourg: Office for Official Publications of the European Communities. Available here. (accessed 09 October 2018).

Davoudi, S., Evans, E., Governa, F. \& Santangel, M. (2008) Territorial governance in the making. Approaches, methodologies, practices, Boletin de la A.G.E., 46(-), pp. 33-52.

Dawson, L., Elbakidze, M., Angelstam, P., \& Gordon J. (2017) Governance and management dynamics of landscape restoration at multiple scales: Learning from successful environmental managers in Sweden. Journal of Environmental Management 197(-), 24-40.

Deyle, R.E., Slotterback. C.S., (2009) Group learning in participatory planning processes: An exploratory quasi experimental analysis of local mitigation planning in Florida. Journal of Planning Education and Research, 29 (1), 23-38.

Eisenhardt, K.M. (1989) Building theories from case study research. Acad. of Manag. Revi. 14 (4), 532-550.

ESPON \& Nordregio (2013) Territorial Approaches for New Governance, Available here (accessed 27 September 2017).

ESPON (2007). Governance of Territorial and Urban Policies from EU to Local Level. Final Report, in: ESPON project 2.3.2, INTERREG III ESPON Programme. Available here. (accessed 09 October 2018).

Faludi, A. \& A.van der Valk (1994) Rule and order: Dutch planning doctrine in the twentieth century. Dordrecht: Kluwer.

Faludi, A. (2012) Multi-level (Territorial) governance: Three criticisms, Planning Theory \& Practice, 13(2): 197-211.

Finlex (2003). Finish Land Use and Building Act (unofficial translation accessed 28 February 2018). Available here. (accessed 09 October 2018).

Flyvbjerg, B. 2004. Phronetic Planning Research: Theoretical and Methodological Reflections. Planning Theory \& Practice, 5(3), 283-306.

Foster, K.A. \& Barnes, W. (2012) Reframing Regional governance for Research and Practice. Urban Affairs Review, 48(2), pp. 272-283.

Gualini, E. (2008) 'Territorial cohesion' as a category of agency: the missing dimension in the EU spatial policy debate. European Journal of Spatial Development, 28(-): 2-22. 
Halpin, D.R., Fraussen, B. Nownes, A. J. (2018) The balancing act of establishing a policy agenda: Conceptualizing and measuring drivers of issue prioritization within interest groups. Governance, 31 (2): 227-237.

Healey, P. (1996) The argumentative turn in planning theory and its implications for strategic spatial planning. Environment and Planning B, 23(2): 217-34.

Healey, P. (2009) In Search of the "Strategic" in Spatial Strategy Making, Planning Theory \& Practice, 10(4), pp. 439-457.

Healey, P. Khakee, A. Motte, A. \& Needham B. (Eds) [1997(2006)] Making Strategic Spatial Plans: Innovation in Europe (Taylor \& Francis e-Library edition published in 2016).

Hersperger, A.M.; Oliveira, E.; Pagliarin, S.; Palka, G.; Verburg, P.; Bolliger, J.; Grădinaru, S., (2018): Urban land-use change: the role of strategic spatial planning. Global Environmental Change, 51: $32-42$.

Hooghe, L. \& Marks, G. (2010) Types of multi-level governance. In: Enderlein H, Wälti S and Zürn M (Eds.) Types of Multilevel Governance. Cheltenham, UK: Elgar, pp. 17-31.

Kahila-Tani, M., Broberg, A., Kyttä, M. \& Tyger, T. (2016) Let the Citizens Map-Public Participation GIS as a Planning Support System in the Helsinki Master Plan Process. Planning Practice \& Research, 31(2): pp. 195-214.

Kunzmann K, (2000) Strategic spatial development through information and communication, IN Salet, W. \& Faludi, A. (Eds) The Revival of Strategic Spatial Planning, Royal Netherlands Academy of Arts and Sciences, Amsterdam, pp 259-265.

Lai, S.-K. (2018) Why plans matter for cities. Cities 73 (2018) 91-95

Laurian, L., Maxine Day, Michael Backhurst, Philip Berke, Neil Ericksen , Jan Crawford, Jenny Dixon \& Sarah Chapman (2004) What drives plan implementation? Plans, planning agencies and developers. Journal of Environmental Planning and Management, 47(4): 555-577.

Legacy, C. \& Leshinsky, R. (2016) Planning Instruments and the Urban Change Process, In: Leshinsky, R., Legacy, C. (Eds.), Instruments of Planning: Tensions and Challenges for More Equitable and Sustainable, Routledge, Oxon and New York, pp. 1-9.

Legacy, C. (2010) Investigating the knowledge interface between stakeholder engagement and planmaking. Environment and Planning A, 42(11), pp. 2705-2720.

Legacy, C. (2012) Achieving Legitimacy Through Deliberative Plan-Making Processes-Lessons for Metropolitan Strategic Planning, Planning Theory \& Practice, 13(1): 71-87.

Malone, T.W. \& Crowston, K. (1990) What is coordination theory and how can it help design cooperative work systems? in: D. Tatar (Ed) Proceeding of the 1990 ACM Conference, pp. 357370. (Los Angeles, USA: ACM Press).

Nadin, V., Smas, L., Schmitt, P. and Cotella, G. (2016) Inception Report of the ESPON COMPASS project - Comparative Analysis of Territorial Governance and Spatial Planning Systems in Europe, ESPON, Available here (accessed 27 September 2017)

Nordregio (2015) Tensions in Nordic urban planning. Nordregio News Issue 2, Available here (accessed 09 October 2018).

Nuissl, H. \& Heinrichs, D. (2011) Fresh Wind or Hot Air - Does the Governance Discourse Have Something to Offer Spatial Planning? Journal of Planning Education and Research, 31(1): 47-59.

Ogilvy, J. (2002) Creating Better Futures. New York, USA: Oxford University Press.

Olesen, K. (2014) The neoliberalisation of strategic spatial planning. Planning Theory, 13(3): 288-303.

Oliveira, E. (2016a) Place branding in strategic spatial planning: an analysis at the regional scale with special reference to Northern Portugal, University of Groningen, Available here. 
Oliveira, E. (2016b) Territorial governance across Europe: Pathways, practices and prospects. Regional Studies, 50(11), pp. 1943-1944.

Oliveira, E. and Hersperger, A. (2018) Governance Arrangements, Funding Mechanisms and Power Configurations in Current Practices of Strategic Spatial Plan Implementation. Land Use Policy, 76, 623-633.

Oliveira, E., \& Hersperger, M.A. (2017) Overcoming Resource Scarcity by Implementing Strategic Regional Plans through Urban-Regional Development Projects: A European Perspective, ASEOP 2017 Lisbon Congress Proceedings. Available here (accessed 17 October 2017)

Paasi, A. \& Zimmerbauer, K. (2016) Penumbral borders and planning paradoxes: relational thinking and the question of borders in spatial planning. Environment and Planning A 48(1): 75-93.

Reimer, M., Getimis, P. \& Blotevogel, H.H. (2014) Spatial Planning Systems and Practices in Europe: A comparative perspective on continuity and changes. (Oxon, UK and New York, USA: Routledge).

Ruming, K. 2012. Negotiating within the context of planning reform: Public and private reflections from New South Wales, Australia. International Planning Studuies, 17, 397-418.

Schmitt, P. \& van Well, L. (2016b) Territorial governance at play Methodological introduction to the case studies, in: P. Schmitt \& L. van Well (Eds) (2016) Territorial governance across Europe: Pathways, Practices and Prospects, Chapter 5, pp. 63-66 (Oxon, UK and New York, USA: Routledge).

Schmitt, P. \& van Well, L. (2016a) Territorial governance across Europe: Pathways, practices and prospects (Oxon, UK and New York, USA: Routledge).

Sellers, J.M.; Arretche, M., Kübler, M. \& Razin, E. (Eds) (2017) Inequality and Governance in the Metropolis - Place Equality Regimes and Fiscal Choices in Eleven Counties. London, UK: Palgrave Macmillan published by Springer Nature.

Shmueli, D.F., Kaufman, S., Ozawa, C. (2008) Mining negotiation theory for planning insights. Journal of Planning Education and Research, 27, 359-364.

Stead, D. (2013) Dimensions of territorial governance. Planning Theory \& Practice, 14 (1): 142-147.

Stead, D. (2014) The Rise of Territorial Governance in European Policy, European Planning Studies, 22(7): 1368-1383.

Tasan-Kok, T. 2008. Changing interpretations of 'flexibility' in the planning literature: From opportunism to creativity? International Planning Studuis, 13(3), 183-195.

van Assche, K., Duineveld, M., Beunen, R. 2014. Power and contingency in planning. Environment and Planning A, 46(10), 2385-2400.

van Well, L. \& Schmitt, P. (2016) Territorial governance across Europe: setting the stage, in: P. Schmitt \& L. van Well (Eds) (2016) Territorial governance across Europe: Pathways, Practices and Prospects, Chapter 1, pp. 3-20 (Oxon, UK and New York, USA: Routledge).

van Well, L., Davoudi, S., Rivolin, U.J., Kovács, I.P. \& Schmitt, P. (2016) Towards future territorial governance, in: P. Schmitt \& L. van Well (Eds) (2016) Territorial governance across Europe: Pathways, Practices and Prospects, Chapter 18, pp. 254-264 (Oxon, UK and New York, USA: Routledge).

Walsh, C. (2014) Rethinking the Spatiality of Spatial Planning: Methodological Territorialism and Metageographies, European Planning Studies, 22(2), 306-322.

Yin, R.K. (2003) Case study research: Design and methods. Sage Publications, Thousand Oaks. 


\section{Funding Source}

This work was supported by the Swiss National Science Foundation ERC TBS Consolidator Grant BSCGIO 157789 CONCUR Project.

\section{Appendix A}

List of the organizations interviewed** and the discussed strategic spatial plans.

\begin{tabular}{|c|c|c|}
\hline Urban region* & Organizations** & Strategic spatial plans discussed \\
\hline Barcelona & $\begin{array}{l}\text { Àrea Metropolitana } \\
\text { Barcelona. } \\
\text { Mediaurban Agency. }\end{array}$ & $\begin{array}{l}\text { Metropolitan Urban Master Plan (PDU) with } \\
\text { references to the General Metropolitan } \\
\text { Plan (PGM) } 1976 .\end{array}$ \\
\hline Cardiff & $\begin{array}{l}\text { Cardiff City Council. } \\
\text { Cardiff University. } \\
\text { Welsh expert of regional } \\
\text { transportation }\end{array}$ & $\begin{array}{l}\text { Strategic Development Plan for the Cardiff } \\
\text { City Region (forthcoming) with references } \\
\text { to the Cardiff Capital Region City Deal and } \\
\text { Cardiff Local Development Plan 2006-2026. }\end{array}$ \\
\hline agen & $\begin{array}{l}\text { Danish Business Authority. } \\
\text { University of Copenhagen. } \\
\text { Rudersdal City Council in } \\
\text { Greater Copenhagen. }\end{array}$ & $\begin{array}{l}\text { The Finger Plan } 2015 \text { - A Strategy for the } \\
\text { Development of the Greater Copenhagen } \\
\text { urban region with references to the Finger } \\
\text { Plan } 2013 \text {. }\end{array}$ \\
\hline Dublin & $\begin{array}{l}\text { Dublin City Council. } \\
\text { Eastern and Midland Regional } \\
\text { Assembly. } \\
\text { University College Dublin. }\end{array}$ & $\begin{array}{l}\text { Regional Planning Guidelines for the } \\
\text { Greater Dublin Area 2010-2022 with } \\
\text { references to the Dublin City Development } \\
\text { Plan 2016-2022. }\end{array}$ \\
\hline urgh & $\begin{array}{l}\text { City of Edinburgh Council. } \\
\text { Strategic Development Planning } \\
\text { Authority For Edinburgh and } \\
\text { South East Scotland. } \\
\text { Royal Town Planning Institute, } \\
\text { Edinburgh, Scotland. } \\
\text { University of Dundee. }\end{array}$ & $\begin{array}{l}\text { Proposed Strategic Development Plan for } \\
\text { Edinburgh and South East Scotland } 2016 \\
\text { and Edinburgh Local Development Plan } \\
2016 \text { with references to the Strategic } \\
\text { Development Plan 2013, to the Action } \\
\text { Programme } 2016 \text { and to the Main Issues } \\
\text { Report } 2015 \text {. }\end{array}$ \\
\hline Hamburg & $\begin{array}{l}\text { Hamburg Metropolitan Region. } \\
\text { HafenCity University Hamburg. }\end{array}$ & $\begin{array}{l}\text { Regional Plan } 2005 \text { with references to the } \\
\text { Regional Development Concept and to the } \\
\text { Strategic Framework } 2010 \text {. }\end{array}$ \\
\hline Hannover & $\begin{array}{l}\text { Region Hannover. } \\
\text { Leibniz University Hannover. }\end{array}$ & $\begin{array}{l}\text { Regional Spatial Planning Program (RROP) } \\
2016 \text { with references to RROP } 2005 .\end{array}$ \\
\hline Helsinki-Uusimaa & $\begin{array}{l}\text { City of Helsinki. } \\
\text { Helsinki-Uusimaa } \\
\text { Council. }\end{array}$ & $\begin{array}{l}\text { Regional Land Use Plan for Helsinki- } \\
\text { Uusimaa } 2016 \text { with references to Helsinki } \\
\text { City Plan - Vision } 2050 \text { Urban plan - the } \\
\text { new Helsinki city plan. }\end{array}$ \\
\hline Lyon & $\begin{array}{l}\text { Le Sepal - Syndicat mixte } \\
\text { d'études et de programmation } \\
\text { de l'Agglomération Lyonnaise. } \\
\text { University Lumière Lyon }\end{array}$ & $\begin{array}{l}\text { Schéma de cohérence territoriale de } \\
\text { l'Agglomération Lyonnaise-SCOT } 2030 .\end{array}$ \\
\hline Milan & Città Metropolitana di Milano. & Piano st \\
\hline
\end{tabular}




\begin{tabular}{r|l|l}
\hline & Politecnico di Milano. & $\begin{array}{l}\text { metropolitan 2016-2018 with references to } \\
\text { "City of cities: A Project for Milan" }\end{array}$ \\
\hline Oslo-Akershus & $\begin{array}{l}\text { Akershus County Council. } \\
\text { Oslo City Council. }\end{array}$ & $\begin{array}{l}\text { Regional Plan for Land Use and Transport in } \\
\text { Oslo and Akershus 2015. }\end{array}$ \\
\hline Stockholm & $\begin{array}{l}\text { Stockholm City Council. } \\
\text { Stockholm County Council. } \\
\text { Nordregio - Nordic and }\end{array}$ & $\begin{array}{l}\text { Regional Development Plan for the } \\
\text { Stockholm Region - RUFS 2010 with } \\
\text { references to the forthcoming RUFS 2050. }\end{array}$ \\
\hline European research centre. & $\begin{array}{l}\text { Verband Region Stuttgart. } \\
\text { Cardiff University (on Stuttgart } \\
\text { case study). }\end{array}$ & $\begin{array}{l}\text { Regional Plan 2009 with references to The } \\
\text { Stuttgart Region's Landscape Park, the } \\
\text { Neckar Landscape Park. }\end{array}$ \\
\hline $\begin{array}{l}\text { Vienna City Council. } \\
\text { Austrian Institute for Regional } \\
\text { Studies and Spatial Planning, } \\
\text { ÖIR. } \\
\text { Vienna University } \\
\text { Technology. }\end{array}$ & $\begin{array}{l}\text { Planning Cooperation for the Spatial } \\
\text { Development of the City Region of Vienna, } \\
\text { Lower Austria and Burgenland 2011 (PGO } \\
\text { 2011) with references to STEP 2025 - } \\
\text { Urban Development Plan Vienna. }\end{array}$ \\
\hline
\end{tabular}

Source: Authors' own. *Alphabetical order; ${ }^{* *}$ Organizations with which the respondents were affiliated. 